\title{
COMBINING LEGAL AND ECONOMIC THEORY. AN INTERDISCIPLINARY APPROACH TO DUTCH AND POLISH FAMILY PROVISIONS IN SUCCESSION LAW
}

\author{
Mark R. Beuker
}

\begin{abstract}
Although testamentary freedom is an important principle in succession law, legislators and judges across the world have recognized the importance of certain family members by granting them mandatory claims in the inheritance of their deceased relative (in spite of wishes of the deceased). This article focuses on these rights. The goal is to introduce the Dutch framework of imperative succession law and to demonstrate the possibilities of combining the legal and economic discipline to deepen knowledge on these provisions. Whilst examples will focus upon succession law, the concepts will be described in a general manner. This might inspire researchers to apply a similar interdisciplinary approach in other fields of law. The imperative provisions that currently exist for family members in the Netherlands can be divided into two types of claims. The first is the legitime, a fixed claim for children of the deceased. The second type are the other statutory entitlements that cover a specified range of situations in which judges have freedom in deciding upon the requests of family members. However, this discretion raises many questions on the way judges should handle such claims. A combination of law and economics can aid in describing and interpreting the law, for example by defining the need for support that is often required for a successful claim. By relying on economic data and theory, judges can come to a more consistent and substantiated way of establishing the need for support.

Mark R. Beuker, MSc, LLM, PhD student, Department of General Law Studies, Faculty of Law, University of Groningen; correspondence address: Oude Kijk in't Jatstraat 26, 9712EK Groningen, The Netherlands; e-mail: m.r.beuker@rug.nl; https://orcid. org/0000-0003-2789-5919.
\end{abstract}


The interdisciplinary methodology can also improve comparative legal research. The functional approach that is common in comparative legal research, assumes that law fulfills certain functions. Economic figures provide an objective basis that demonstrates what functions a law fulfills and to what extent this is done efficiently. This information can be used to compare the functioning of laws in different countries.

Keywords: interdisciplinary, family provisions, economics, comparative

\section{INTRODUCTION}

This contribution describes the Dutch inheritance claims that family members can have in an estate in spite of the wishes of the deceased. Furthermore, it demonstrates the possibilities of a legal-economic approach to these imperative claims in succession law. This means the law will not only be analyzed in a traditional doctrinal manner, but also from an economic perspective. Combining these disciplines can deepen the descriptive and interpretive value of legal research, as well as facilitate comparison. Given the general nature of economic theory, this methodology can also be used in other fields of (legal) research. Hence, this article can also be interesting for scholars who are concerned with the application of a legal-economic approach in other fields of law.

As mentioned, this article will specifically apply the legal-economic approach to analyze inheritance claims that family members can have in an estate, regardless of the wishes of the deceased. This topic is one of the most fundamental questions in inheritance law. In civil law countries such as the Netherlands and Poland, the legitime (also known as statutory portion, forced heirship or legitima portio) is the most famous example of an imperative claim by family members. This right differs between countries, but it entitles certain family members to a forced share or monetary claim in the estate. It is however not the only provision that protects family. The Netherlands for example also have a range of other provisions that benefit a varied range of persons.

The first paragraph introduces the Dutch framework of mandatory family protection in succession law. The second paragraph will analyze three examples of this and of the Polish system in more detail to illustrate 
the application of the legal-economic approach. First, descriptive economics demonstrates what role the legitime plays in Dutch society. Second, financial figures will be used to interpret the need for support that is required for certain claims. Third, drawing on examples of Dutch and Polish law, the legal-economics approach will show possibilities for comparative research.

\section{THE FRAMEWORK OF FAMILY PROTECTION}

\subsection{The legitime}

Since 2003, Dutch succession law contains two sorts of imperative claims that family members can have in spite of wishes of the deceased. The oldest is the legitime. This right entitles specific persons to a fixed claim in the inheritance. It is not based on the needs of the claimant. Nowadays, this provision does not grant the Dutch claimant a share in the inheritance, as was the case in Roman law, but merely a right to a sum of money. Hence, technically, invoking the legitime does not lead to forced heirship, but only a monetary claim, art. 4:63 Burgerlijk Wetboek (hereafter: BW). ${ }^{1}$

Many Dutch scholars are in favor of abolishing the legitime as they consider it an unjustified infringement in testamentary freedom. ${ }^{2} \mathrm{How}-$ ever, there is also academic support for the legitime. ${ }^{3}$ Furthermore, empirical legal research demonstrates that many Dutch people still support

Burgerlijk Wetboek is the Dutch Civil Code.

2 See e.g. Wilbert D. Kolkman, "Pleidooi voor afschaffing van de legitieme portie," in Dwingend erfrecht in Europa, eds. René J.C. Flach, Grietje T. de Jong, Rosalie Koolhoven, and Fokke J. Vonck (Den Haag: Boom Juridische Uitgevers, 2015), 71-83; Lucienne A.G.M. van der Geld and Freek W.J.M Schols, Legitieme portie. Een eerstelijns - en nader voort te zetten - veldonderzoek naar de wenselijkheid van de legitieme portie in het hedendaagse erfrecht (Centrum voor Notarieel Recht, Radboud Universiteit en Netwerk Notarissen, 2020), 73-95.

3 Johannes H.M. ter Haar, "Is de legitieme portie nog legitiem?," Tijdschrift Erfrecht 2 (2021): 23-29. 
the legitime and it cannot be concluded that a majority of the population is in favor of abolishing the legitime. ${ }^{4}$

In the Netherlands, only children are entitled to a legitime. If a child has predeceased, his or her descendants can claim the legitime in his or her place. The right is solely based on the relationship with the deceased; there is no requirement that the child actually needs money. Any child has a right to a legitime. However, assets that the child acquires from its parent's inheritance diminish the value of the child's claim. The same applies to assets the child could have acquired from the estate, but rejected, unless certain conditions were attached to the bequest that made it inferior, art. 4:71 ff BW. Furthermore, as is common in European law, the child will lose the claim if it is convicted of certain criminal offences against the deceased parent, art. 4:3 BW. Apart from this rule, there is no possibility for a parent to prevent the child from claiming its legitime.

The legitime is usually worth half of what would be the child's entitlement if Dutch intestate succession law would be applicable. If intestate succession is applicable, the estate has to be divided equally between all children and the surviving spouse. ${ }^{5}$ So, if the deceased leaves a surviving spouse and two children, the claim according to intestate succession would amount to $1 / 3$ of the inheritance. It should be added that this claim is only due after the death of the surviving spouse. However, this does not influence the amount of the claim of a child. As the legitime is half of this amount, a child can claim 1/6 of the inheritance based on the rules of the legitime.

If the deceased parent gave away property during his or her life, this can influence the size of the legitime. For example, money given to a child diminishes the amount of the legitime by the amount of the gift (art. 4:70 BW). Gifts to other children enlarge the claim of the child that did not receive money (art. 4:67 sub d BW). These clawback rules prevent easy circumvention of imperative law, but also complicate rules

4 Mark R. Beuker, "Rapport Legitieme Portie; wil het publiek aanpassing van de legitieme portie?," Tijdschrift voor Familie- en Jeugdrecht 29, afl. 5 (2021): 134-138.

See art. 4:64 ff BW. 
and can lead to court cases. Many court cases revolve around the right of children to acquire the information they need to calculate their right. ${ }^{6}$

The position of the person entitled to a legitime cannot be understood without taking into account the right of a surviving spouse. If the deceased leaves a spouse or registered partner, the legitime might not be able to immediately demand payment of the legitime. The testator can arrange that the legitime can only demand payment after the death of the surviving spouse. ${ }^{7}$ The same could be the case if the deceased leaves an unmarried cohabitant with whom he or she had a notarial contract arranging the common household of the two persons involved. ${ }^{8}$ The surviving spouse or unmarried cohabitant even has the right to use and sell all goods in the inheritance, leaving the child with a claim that cannot be paid even after death of the surviving spouse or unmarried cohabitant.

\subsection{Other statutory entitlements}

The other mandatory claims in Dutch succession law are called other statutory entitlements. They are a collection of different rights that each have their specific requirements. They can roughly be divided in rights for the surviving spouse and rights for other family members. Usually, they require the claimant to have a need for these claims. Judges have wide discretion in interpreting these claims and establishing their size. This freedom can and does however sometimes lead to unpredictable outcomes.

\subsubsection{Other statutory entitlements for the surviving spouse}

The most important claim is the right of the surviving spouse to a usufruct of the inheritance. Also the registered partner of the deceased is entitled to this claim. The usufruct enables the surviving spouse to keep using

Beuker and Kolkman, unpublished research data collected for vFAS (2015).

7 Art. 4:81 BW. If there is no will, the legitime is only payable after the death or bankruptcy of the surviving spouse (art. 4:81 lid $2 \mathrm{BW}$ ). If a will is present, the legitime still is not due if the surviving spouse can claim a usufruct (see hereafter, paragraph 2.2.1 and art. 4:81 lid $3 \mathrm{BW}$ ). All this only applies insofar the estate transfers to the surviving spouse or partner.

8 Note that in this case the testator has to actively arrange that de legitime will only be due after the death of the partner, art. 4:82 BW. 
goods of the inheritance that were property of the deceased. The usufruct lasts until the death of the surviving spouse. Selling is only possible if the judge explicitly gives permission to do so.

As the other statutory entitlements merely function as a safety net in specific cases, a usufruct will only be granted if the surviving spouse is in need for this. The spouse who has enough financial needs to support himor herself is supposed to use his or her own assets. However, the legislator assumes that the spouse has a need for a usufruct on the house and furniture (art. 4:29 BW). Therefore, merely invoking the right to a usufruct on the house and furniture obliges the heirs of the estate to cooperate in establishing a usufruct. If the heirs or other beneficiaries contest the need for the usufruct, it is up to them to prove that the surviving spouse can manage without the house and furniture. ${ }^{9}$

If the surviving spouse also (or only) wishes a usufruct on other goods of the inheritance than the house and furniture, he or she has to prove the need for this usufruct (art. 4:30 BW). Apart from the usufruct, the surviving spouse can often benefit from another entitlement. This right grants the spouse a right to continue living in the house of the deceased for a period of six months. Albeit this facility being merely a temporary solution for possible housing problems of the surviving spouse, it can fulfil a major role in settling the inheritance. This is because the right does not have to be invoked by the surviving spouse (contrary to the usufruct). Therefore, during the time that a usufruct has not been established, or the need for this usufruct is being contested, the surviving spouse can nevertheless remain in the house of the deceased thanks to the right of art. 4:28 BW. Persons entitled to this right are not only the spouse (art. 4:28 lid 1 BW), but also any other person who had a common household with the deceased (art. 4:28 lid 2 BW). ${ }^{10}$

9 Dutch Parliamentary History, Kamerstukken II 1999/2000, 27021, no. 3.

10 It is sometimes suggested that this right should continue even after the six month period, in case the surviving spouse has claimed a usufruct which has not been granted. Steven Perrick, Mr. C. Assers Handleiding tot de beoefening van het Nederlands Burgerlijk Recht. 4. Erfrecht en schenking (Deventer: Wolters Kluwer, 2017), no. 364. 


\subsubsection{Other statutory entitlements for other family members}

The other statutory entitlements do not only protect the surviving spouse, but also children of the deceased and certain other persons. Minor and young children can for example claim a sum of money that the heirs have to pay at once for upbringing and education (a lump sum). This right exists for children younger than 21 years and can only be claimed for the costs of upbringing and education until the $21^{\text {st }}$ birthday. It is available also if the child has enough money to pay these things itself. However, no right is granted if a surviving spouse is obliged to take care of the child.

The lumpsum takes priority over the rights of a surviving spouse. It can therefore be considered a strengthened legitime. ${ }^{11}$

Another lump sum is available for children, step children, children in law and grandchildren of the deceased, art. 4:36 BW. It can be claimed if one of these persons has worked for the deceased's household or business without having received appropriate financial compensation. It is also required that the work has been carried out while the person was adult; if the child was still a minor, the work often is assumed to have characteristics of an internship in which the child learns things. Establishing what should be considered appropriate financial compensation can be quite challenging. The judge should also take into account non-monetary benefits the person has received, such as education or living within the household of the deceased without having to pay for the costs of the household. Judges tend to be strict when interpreting this provision. They usually only award a claim if the claimant had economic disadvantages by performing work for the deceased.

The last other statutory entitlement aims to protect economic interests by facilitating the continuity of businesses. If a child, step-child or spouse of one of these persons in practice already continues the business activities of the deceased, he or she can claim assets in the inheritance that are necessary for this business by application to the judge. The claim will only be awarded if it fulfils an important need of the claimant and awarding the claim will not gravely damage the interests of the person(s) who is/are entitled to the assets. The claimant will have to pay a reasonable

11 Johannes H.M. ter Haar, "Minderjarigen en (de zorg voor) hun vermogen” (PhD diss., University of Groningen, 2013), 157-84. 
price for the business assets that are being taken over. This claim can be made if the business goods were private property of the deceased, but also if the business was shaped as a corporation. However, in the latter case the claimant does not acquire specific business goods, but the shares in the corporation. In that case, it is required that the deceased was a director of the corporation and that he or she (possibly together with the other directors) possessed a majority of the company's shares. Furthermore, the child, step-child or spouse of one of these persons had to be a director of the company when the deceased died or he or she has to function as the successor in the company of the deceased. ${ }^{12}$

\section{EXAMPLES OF THE LEGAL-ECONOMICS APPROACH}

Hitherto, the text has focused upon introducing the mandatory claims that are present in Dutch succession law. To understand these claims more deeply, the following paragraphs will analyze certain aspects of these claims by applying a legal-economics approach. The aim of these analyses is not to evaluate in detail the working of these provisions given the limited space in my contribution. The goal is to illustrate the way in which the combination of legal and economic theory can strengthen knowledge on the legal rules by means of describing, interpreting and comparing them. ${ }^{13}$

\subsection{Example 1: describing entitlements to the legitime}

Traditionally, legal theory is concerned with describing the consequences of legal rules by doctrinal reasoning. It might for example demonstrate the implications of a rule in succession law, by interpreting it in relation to family property law. If the protection of the surviving spouse seems limited in succession law, it might seem that this spouse has a bad position.

12 Wouter Burgerhart, "Waarde en erfrecht" (PhD diss., University of Nijmegen, 2008), 162-68 and 446-52 provides a more detailed interpretation of this provision.

13 Although more often used in trust law, this approach has not been widely used in succession law. An interesting example is e.g. provided by Daniel B. Kelly, "Toward Economic Analysis of the Uniform Probate Code," University of Michigan Journal of Law Reform 45, no. 4 (2012): 855-98. 
However, strict rules in family property law that lead to a 50-50 division of property of the spouses might take away the hard edges of succession law. This widespread approach to law provides a bigger picture of the functioning of the law by taking into account the importance of other legal fields. However, it is not suitable to describe how effective the law is in fulfilling certain functions. Economics can help in quantifying and evaluating the impact of laws. ${ }^{14}$ This might show that certain rules only apply to a limited number of cases and are therefore not very important in practice. An example of the legal-economic approach in succession law demonstrates how the legitime works out for children. After analyzing the requirements for claiming a legitime, it is interesting to research how many people can claim this right, what is the value of their entitlement and when they are able to actually collect the money. This was possible by using data from the Dutch national statistics office (CBS), an independent, government funded organization that is responsible for providing data on many societal subjects. By searching for data and combining data, it was possible to show that the average claim of a child, following from the legitime, amounted to $€ 19,866.00$ in $2016 .{ }^{15}$ However, large differences exist when it comes to the sizes of estates and of the legitime. ${ }^{16}$ Another interesting finding is that the age at which a child receives its legitime is quite high. More than $66 \%$ of the deceased were older than 76 years when they died, which implies that also the children entitled to a legitime were already not young anymore. Legal researchers already noted that the changes in society (and life expectancy) influenced (and diminished) the role of inheritances for the lives of children. ${ }^{17}$ However, only this economicl sociological data proves the role of the legitime in modern-day society. It is sometimes stated that the legitime fulfills a function in caring for

14 Antony W. Dnes, “Economics and Family Law,” 2018, https://papers.ssrn.com/sol3/ papers.cfm?abstract_id $=3248776,1-40$ provides multiple concrete examples of the impact that legal change has on societal behavior.

15 Mark R. Beuker, "De legitieme gekwantificeerd," Weekblad voor Privaatrecht Notariaat en Registratie 7313 (2021): 147-52.

16 "Nalatenschappen; Nagelaten vermogen, kenmerken," CBS, Den Haag/Heerlen, 2020, https://opendata.cbs.nl/statline/\#/CBS/nl/dataset/84242NED/table?dl=47817.

17 John H. Langbein, "The Twentieth-Century Revolution in Family Wealth Transmission," University of Chicago Law Occasional Paper 25 (1989): 1-32. 
family members. Polish legal research also explicitly acknowledges the social support function of the legitime. ${ }^{18}$ However, the finding that many children receive a legitime only at an older age, questions the need for a legitime if claimants are often (soon) able to support themselves because of Dutch social provisions for elderly (AOW) or because they are usually working. However, it is good to notice that many situations differ from the average and that also young children are entitled to a legitime in the more rare cases that their parent dies.

The approach can also be applied to describe how much testamentary freedom testators have. Because of the legitime, roughly $37 \%$ of the value of inheritances can pass to children even if this is contrary to the wishes of the deceased. This figure does not even take into account the claims that can be made based on the other statutory entitlements. However, in $40 \%$ of the cases, there is a possibility that the children cannot immediately demand payment of their legitime. In these cases, there is a surviving spouse who could be entitled to all goods in the inheritance and also has the possibility to use (and sell) all these assets, possibly leaving the child of the deceased with a claim that later proves to be worthless as there is no money left. This economic research shows how the legitime works out in practice and can help in evaluating to what extent the law fulfils its function. Whilst the claim might seem a large infringement on testamentary freedom, it might prove to be less important as the child often has to wait before receiving its claim and possibly will not receive anything at all. If one of the aims of the legitime is the protection of children, these data pose questions as to how successful the current rules are in granting this protection.

\subsection{Example 2: interpreting the necessity-criterion for the surviving spouse by relying on economic parameters}

Certain societal developments, such as an increase in divorce rates and the popularization of unmarried cohabitation, lead to more diverse family

18 Fryderyk Zoll, "Compulsory Portion in Poland," in Comparative Succession Law v3 Mandatory Family Protection, eds. Kenneth G.C. Reid, Marius J. De Waal, and Reinhard Zimmermann (Oxford: Oxford University Press, 2020), 371 and, more specifically, the references in footnote 52 of Zoll's contribution. 
structures. Those relationships require a more tailor-made approach to imperative inheritance law. Whilst the benefits of provisions that are more based on the specific needs of family members is clear, it is not always easy to tailor-make the rights of possible claimants. The Dutch legislator introduced the other statutory entitlements that leave much discretionary freedom with the judge to take into account all relevant matters in establishing the right provision.

However, in legal practice it is not always easy to discern what factors are relevant and which are not. The legal-doctrinal approach is only to a certain extent well-equipped to aid judges (and other legal practitioners) in their interpretation of discretionary freedom. Judges in the Netherlands have therefor come to differing conclusions and taken into account different aspects of a case, and also weighing these aspects differently. ${ }^{19}$ The same applies to the UK where judges have discretion in awarding family provisions, but where it is unclear how different factors should be weighed. This leads to an increase in court cases and a wish for more guidance on the interpretation of the statute. ${ }^{20}$

Questions often revolve around the concepts of 'necessity' or 'reasonability'. ${ }^{21}$ Economics can provide benchmarks for researching what is necessary or reasonable by showing what average costs and income persons or household have that are in a similar situation (maybe depending upon the presence of children, age and other relevant factors). Furthermore, economics can also establish an absolute minimum amount of money that is required to live. It can also take into account the financial

19 Two cases on the lumpsum ex art. 4:35, namely Rechtbank Amsterdam 30-092010, ECLI:NL:RBAMS:2010:BO8410 and Rechtbank Midden-Nederland 05-12-2014, ECLI:NL:RBMNE:2014:7147.

20 See e.g. Re Ilott v. The Blue Cross and others, [2017] 2 WLR 979; and Rodger Kerridge, "Family Provision in England and Wales," in Comparative Succession Law v3 Mandatory Family Protection, eds. Kenneth G.C. Reid, Marius J. De Waal, and Reinhard Zimmermann (Oxford: Oxford University Press, 2020), 409-10.

21 This is the case in the Dutch other statutory entitlements: the need for usufruct for the surviving spouse (art. 4:29 and 4:30 BW), the lump sums for minors and young adults can be claimed insofar they are needed (art. 4:35), the lump sums for unpaid labor will be paid to provide reasonable compensation (art. 4:36) and business goods can be taken over for a reasonable price (art. 4:38 BW). 
position of the testator or his or her beneficiaries. An example can be given for the interpretation of the usufruct for the surviving spouse. As was described in 2.2.1, the usufruct entitles the surviving spouse to use inheritance goods for the rest of his or her life. However, the most important requirement to receive the usufruct is that the spouse should need this right; if he or she has enough financial means, no right exists. Economic data can be used to estimate what needs a person, such as a surviving spouse, has. These needs are based on certain costs of living. The Dutch Nibud and CPB publish data on the amount of money people need/use for the costs of living. The CBS has figures of the actual spending of households. ${ }^{22}$ Relying on these data, it is possible to establish what are the exact minimum needs to be able to buy the most basic things to survive. It is also possible to research what average income and costs a certain person is expected to have. These costs depend on many factors. The income of the former household of the deceased and his or her spouse is usually a major factor in the spending pattern that the surviving spouse is used to. Age is another factor that should be taken into account; persons spend more money when they grow older, but after retiring, spending and income usually drop. Also the presence of children can play a role in the financial situation. Taking such factors into account, makes it possible to determine the need of the surviving spouse.

The spouse is not always entitled to continue living at the same standards of living after the death of the testator. The deceased's testamentary wishes are also important, which can render it reasonable that the surviving spouse has to accept a lower standard of living. Economics can take into account this value of testamentary freedom in the following way. The surviving spouse will always at least be entitled to a usufruct that guarantees the absolute minimum needs that have been calculated as mentioned in the last paragraph. Afterwards, there might be a need for more luxurious goods. After the absolute minimum is guaranteed, it seems fair to 'divide' the rest of the assets of the estate (the ones left after the usufruct to guarantee a minimum standard of living) between the heirs and the surviving

22 Bestedingen van huishoudens; huishoudenskenmerken, bestedingscategorieën. Den Haag/Heerlen: CBS, 2019, https://opendata.cbs.nl/statline/\#/CBS/nl/dataset/83678NED/ table? $\mathrm{dl}=43 \mathrm{C} 3 \mathrm{~A}$. 
spouse. The result will be that only a maximum of half of those remaining assets will be subject to a usufruct, whilst the other half will immediately be available for the beneficiaries of the estate. Of course, if the need for luxurious goods is smaller than half of the remain assets, the usufruct will entail less than half of those assets. It should be noted that this is not a legal division, as there is no communal property between the surviving spouse and the beneficiaries and because the surviving spouse will not own any goods, but merely receive a usufruct.

A similar approach is already used in Dutch law when it comes to maintenance for spouses after divorce. The Alimentatienormen, a set of guidelines made by judges, provide direction for the calculation of maintenance. ${ }^{23}$ Those calculations are greatly influenced by financial data on the situation of the spouses and the costs of living in the Netherlands.

\subsection{Example 3: facilitating comparison of the Dutch and the Polish legal system}

The functional approach to comparative law has become quite influential, if not standard. ${ }^{24}$ This method for comparing legal systems does not only consider the meaning of specific areas of law, but analyzes in what ways different laws fulfil a specific function. Here, it is useful to take into account again the first lines of paragraph 3.1 where it is described that the spouse might be well protected, even though rules in succession law seem harsh, because matrimonial property law provides greater protection. Only considering the content of succession law will lead to an unfair representation of the system being researched.

This example shows that this wide approach to comparative law protects researchers from having a focus that is too narrow and from overlooking other relevant fields of law. However, it does not make clear in what societal circumstances these field of law operate. Societies

23 Rapport Expertgroep Alimentatienormen 2021 (Utrecht: De Rechtspraak, 2020), $1-69$. See also the attached tables for establishing the need for child support and the ability of the other spouse to pay this support.

${ }_{24}$ Konrad Zweigert and Hein Kötz, An Introduction to Comparative Law, trans. Tony Weir (Oxford: Oxford University Press, 1998), 32-47. 
can differ enormously when it comes to for example wealth, income, but also individuality and labor market participation. Economic data can provide objective criteria that describe how laws work out in a specific society. This leads to empirical evidence showing to what extent the law is successful in fulfilling the function that is being researched. Sometimes, inheritances are quite small if a lot of property is part of a matrimonial property regime. Or, as is the case in England \& Wales, the house usually automatically becomes property of the surviving spouse. Using economic data to describe the value of the house and the value of the inheritance in both countries can provide for a comparison of legal systems that depicts a more fair image of the way laws really work to fulfil a certain function, such as protecting the surviving spouse. ${ }^{25}$

When it comes to comparing Dutch and Polish succession law, it seems at first glance that rules on mandatory family protection differ to a major extent. However, the differences might not be so large in practice. The Dutch system for example does not provide protection for parents of the deceased while the Polish law does. However, economics shows that not a lot of children die before their parents. And, when they do, they often have a spouse and/or child(ren). In that case, also in Polish law, no claim exists for the parent of the deceased. ${ }^{26}$

The same applies to grandparents. No right exists in the Netherlands, but if it would exist, it probably would not often be applicable. Polish law awards a claim to grandparents that live below the poverty line, but in the Netherlands grandchildren do not often die before their grandparents. And when they do, those grandparents are often entitled to social security and pension benefits as the Dutch save a lot of money for retirement. This would often render a claim unsuccessful.

Also when it comes to comparing rules on unmarried cohabitation the Netherlands might in general appear to be different from Poland, but when looking at mandatory rules in succession law, it shows

25 Richard A. Posner, Economic Analysis of Law (New York: Little, Brown \& Co., 1973), 193-212 describes the basics of an economic approach within the context of the family.

26 Fryderyk Zoll, "Compulsory Portion in Poland," in Comparative Succession Law v3 Mandatory Family Protection, eds. Kenneth G.C. Reid, Marius J. De Waal, and Reinhard Zimmermann (Oxford: Oxford University Press, 2020), 371-72. 
that the unmarried partner does not get much protection. To explain the similarities and differences, economic data can be relevant. Societal developments happen at different speed. In the Netherlands, unmarried partnership was already popular for a longer time than in Poland. ${ }^{27}$ That is probably why, in general, unmarried partners can more easily arrange formal aspects of their relationship. However, they hardly have any claims in imperative succession law as the basis for these claims lies in a more formal family relationship. Only the right to remain in the house of the deceased for half a year might be applicable, art. 4:28 BW. When it comes to business continuity, Poland might introduce a right somewhat similar to the Dutch rules on taking over businesses. ${ }^{28}$ Economic theory positively interprets business activities. When more problems regarding business continuity arise in society, the legislator will start considering a provision in the law to safeguard economic interests. Recent waves of interest in governance related questions have also shifted the focus of researchers and lawmakers to the importance of family business continuity. ${ }^{29}$ The market changes that have increased the wealth of Polish businesses have also increased the need for facilities that enable business continuity. ${ }^{30}$ This economic background renders more logical the introduction of the Dutch-like provision to enable the transfer of businesses in mandatory succession law.

27 Anna Matysiak, "Is Poland really immune to the spread of unmarried cohabitation?," Demographic Research 21, no. 8 (2009): 215-34 on the development of unmarried cohabitation.

28 Fryderyk Zoll, "Compulsory Portion in Poland," in Comparative Succession Law v3 Mandatory Family Protection, eds. Kenneth G.C. Reid, Marius J. De Waal, and Reinhard Zimmermann (Oxford: Oxford University Press, 2020), 370.

29 Aleksander Surdej and Krzysztof Wach, "The dynamics of succession in family businesses in Poland - Empirical results," Economia Marche: Journal of Applied Economics 31, no. 2 (2012): 109-28.

30 Elżbieta Roszko-Grzegorek, "The Role and Importance of Succession Planning in Polish Family Firms," Acta Universitatis Lodziensis. Folia Oeconomica 224 (2008): 57-79. 


\section{CONCLUSION}

Major differences exist in the ways in which legal systems protect the interests of family members in inheritance law. Current Dutch law has two types of claims that are rather different in nature. The legitime is a fixed claim for descendants, whilst the other statutory entitlements are open to a wider range of family members whose needs form the basis of the right that is to be awarded by a judge who has considerable discretionary freedom.

This article exemplifies the possibilities of applying an interdisciplinary legal-economic approach to succession law. Economics make clearer how rules work out in society, which can help evaluate their functioning. Furthermore, economics have proven useful in interpreting legal concepts. The economic figures aid in establishing the interpretation that is most in line with legal doctrine or most efficient. Lastly, economics can function as a discipline that provides objective measures by which legal systems can be compared. This promises to be a valuable tool for a more in-depth comparison of legal systems.

\section{REFERENCES}

Beuker, Mark R. "Rapport Legitieme Portie; wil het publiek aanpassing van de legitieme portie?." Tijdschrift voor Familie- en Jeugdrecht 29, afl. 5 (2021): 134-138.

Beuker, Mark R. "De legitieme gekwantificeerd.” Weekblad voor Privaatrecht Notariaat en Registratie 7313 (2021): 147-52.

Burgerhart, Wouter. "Waarde en erfrecht." PhD diss., University of Nijmegen, 2008.

CBS. "Nalatenschappen; Nagelaten vermogen, kenmerken." Den Haag/Heerlen, 2020. https://opendata.cbs.nl/statline/\#/CBS/nl/dataset/84242NED/ table? $\mathrm{dl}=47817$.

Dnes, Antony W. "Economics and Family Law.” 2018. https://papers.ssrn.com/ sol3/papers.cfm?abstract_id=3248776.

Van der Geld, Lucienne A.G.M., and Freek W.J.M Schols. Legitieme portie. Een eerstelijns - en nader voort te zetten - veldonderzoek naar de wenselijkheid 
van de legitieme portie in het hedendaagse erfrecht. Centrum voor Notarieel Recht, Radboud Universiteit en Netwerk Notarissen, 2020.

ter Haar, Johannes H.M. "Minderjarigen en (de zorg voor) hun vermogen." $\mathrm{PhD}$ diss., University of Groningen, 2013.

ter Haar, Johannes H.M. "Is de legitieme portie nog legitiem?.” Tijdschrift Erfrecht 2 (2021): 23-29.

Kelly, Daniel B. "Toward Economic Analysis of the Uniform Probate Code." University of Michigan Journal of Law Reform 45, no. 4 (2012): 855-98.

Kerridge, Roger. "Family Provision in England and Wales." In Comparative Succession Law v3 Mandatory Family Protection, edited by Kenneth G.C. Reid, Marius J. De Waal, and Reinhard Zimmermann, 384-416. Oxford: Oxford University Press, 2020.

Kolkman, Wilbert D. "Pleidooi voor afschaffing van de legitieme portie." In Dwingend erfrecht in Europa, edited by René J.C. Flach, Grietje T. de Jong, Rosalie Koolhoven, and Fokke J. Vonck, 71-83. Den Haag: Boom Juridische Uitgevers, 2015.

Langbein, John H. "The Twentieth-Century Revolution in Family Wealth Transmission." University of Chicago Law Occasional Paper 25 (1989): 1-32.

Matysiak, Anna. "Is Poland really immune to the spread of unmarried cohabitation?.” Demographic Research 21, 8 (2009): 215-34.

Perrick, Steven. Mr. C. Assers Handleiding tot de beoefening van het Nederlands Burgerlijk Recht. 4. Erfrecht en schenking. Deventer: Wolters Kluwer, 2017.

Posner, Richard A. Economic Analysis of Law. New York: Little, Brown \& Co., 1973.

Rapport Expertgroep Alimentatienormen 2021. Utrecht: De Rechtspraak, 2020.

Roszko-Grzegorek, Elżbieta. "The Role and Importance of Succession Planning in Polish Family Firms.” Acta Universitatis Lodziensis. Folia Oeconomica 224 (2008): 57-79.

Surdej, Aleksander, and Krzysztof Wach. "The dynamics of succession in family businesses in Poland - Empirical results." Economia Marche: Journal of Applied Economics 31, no. 2 (2012): 109-28.

Zweigert, Konrad, and Hein Kötz. An Introduction to Comparative Law. Translated by Tony Weir. Oxford: Oxford University Press, 1998.

Zoll, Fryderyk. "Compulsory Portion in Poland." In Comparative Succession Law v3 Mandatory Family Protection, edited by Kenneth G.C. Reid, Marius J. De Waal, and Reinhard Zimmermann, 366-83. Oxford: Oxford University Press, 2020. 
